
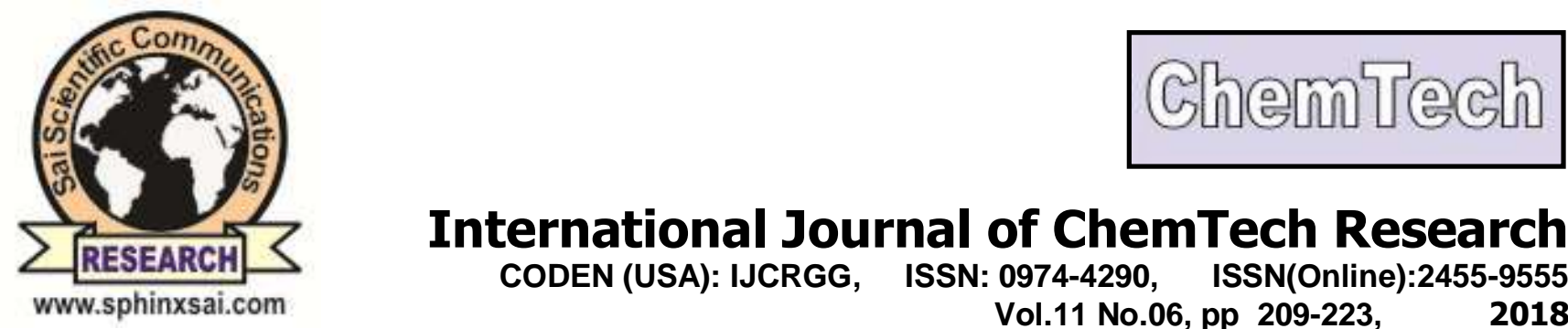

International Journal of ChemTech Research CODEN (USA): IJCRGG, ISSN: 0974-4290, ISSN(Online):2455-9555

Vol.11 No.06, pp 209-223,

2018

\title{
Correlating Antimicrobial activity and Structure in Montmorillonite modified with Hexadecyltrimethylammonium and Silver
}

\author{
Alejandra María Fernández Solarte ${ }^{1,2, ~ \#, ~}$ \\ Mariana Blanco Massani ${ }^{3,4, \#, \star}$, Vanesa Molina ${ }^{3}$, \\ Mónica Benítez Guerrero ${ }^{5}$ and Rosa M. Torres Sánchez ${ }^{1,4}$
}

${ }^{1}$ Centro de Tecnología de Recursos Minerales y Cerámica (CETMIC- CCT La Plata-

CIC), Camino Centenario y 506, (1897) M. B. Gonnet, La Plata, Argentina.

${ }^{2}$ present address. Corporacion Universitaria Minuto de Dios, Cra. 74 \#81 C-05, Bogotá, Colombia

${ }^{3}$ Instituto Nacional de Tecnología Industrial (INTI), Av. Gral. Paz 5445 (1650), San Martin, Argentina.

${ }^{4}$ Consejo Nacional de Investigaciones Científicas y Técnicas (CONICET), Av. Rivadavia 1917 (C1033AAJ), Buenos Aires, Argentina

${ }^{5}$ Universidad de Málaga. Departamento de Ingeniería Civil, Materiales y Fabricación. C. Dr. Ortiz Ramos s/n, 29071, Málaga, Spain

\begin{abstract}
The relationship between antimicrobial properties and structure of montmorillonite (MMT) containing hexadecyltrimethylammonium bromide (HDTMA-Br) and silver (Ag) was determined. HDTMA was adsorbed at the clay interlayer by a cation exchange, through the positive head of the ammonium group. At higher surfactant loadings (100 and 200\% cation exchange capacity (CEC); MH1 and $\mathrm{MH} 2$ samples, respectively) the prevalence of weak adsorption (Van der Waals forces) was observed; whereas below the clay CEC (50\%, MH0.5) strong interactions predominated (cation exchange). These different interactions impacted on antimicrobial activity, increasing bactericidal capacity when the surfactant was more available to diffuse. For organo-montmorillonites (OMMT) and all samples with Ag, zeta potential pointed out electrical charge changes on the outer surface, respect to MMT. XPS analyses showed peaks attributed to clusters formation, silver oxidation, and $\mathrm{Ag}^{0}$ in MMT-

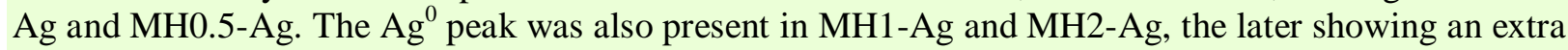
peak associated with $\mathrm{AgBr}$. HDMTA ${ }^{+}$and $\mathrm{Ag}$ adsorbed on the MMT acted synergistically against Staphylococcus aureus. This effect was less noticeable for Escherichia coli and the result was attributed to both, E. coli outer envelope which might lower the efficacy of $\mathrm{HDMTA}^{+}$adsorbed on the MMT, and decreasing silver proportions when the surfactant loading increased. MH1-Ag presented the best bactericidal properties, showing synergistic effects against $S$. aureus, while maintaining activity against E. coli compared to MMT-Ag. Understanding MMT-HDMTA-Ag efficacy contributes to the design of new antimicrobial materials for potential applications in health care.

Key words : Synergistic bactericidal activity, Staphylococcus aureus, Escherichia coli, Modified montmorillonite, Hexadecyltrimethylammonium, Silver.
\end{abstract}




\section{Introduction}

Over the last years, considerable work has been dedicated to developing highly efficient strategies to fight bacteria. In this regard, the combination of different antimicrobials such as metal ions, nanoparticles, bacteriocins, as well as plant-derived compounds has been reported ${ }^{1}$. The use of quaternary ammonium compounds (QAC) was also suggested as they are less susceptible to development of resistance by the bacteria ${ }^{2}$. Particularly, hexadecyltrimethylammonium bromide (HDTMA-Br), also known as cetyltrimethylammonium bromide, showed antimicrobial effect either alone or interacting with inert or non-inert vehicles; or as a part of polymers ${ }^{2,3}$. The use of silver as antimicrobial agent has also been extensively studied ${ }^{4-6}$.

Not only because of its large cation-exchange capacity (CEC), surface area, and swellability, but also because of its biocompatibility, montmorillonite has been used in a wide range of practical applications ${ }^{7-9}$. The use of montmorillonite (MMT) to support different antimicrobials was previously studied for the inhibition of gram-positive and gram-negative bacteria. Its antimicrobial activity showed to be dependent on the antimicrobials used and the assayed microorganisms. That is, for QAC the antibacterial activity occurred mainly through the surfaces interactions between the ammonium compound on the MMT surface and cell envelopes, and less antimicrobial effectiveness against gram negatives was observed ${ }^{7,10}$. Besides for heavy metal cations exchanged in MMT, antimicrobial activity was informed to arise from both the loaded ion and the cation released from the surface of the clay ${ }^{7,11-13}$. Either for QACs or heavy metals, the cation excess on the clay mineral surface led to a positive charge formation, attracting the negatively charged cell envelope ${ }^{10,11}$. The application of antimicrobial MMT supported with $\mathrm{Ag}^{+}$, silver nanoparticles, or different QAC at varying loading levels was reported ${ }^{8,14-17}$. Nonetheless, to the best of our knowledge, there are no studies addressing the relationship between materials antimicrobial activity, cations loading content and their interlayer arrangements, when clay mineral involve the concomitant use of HDTMA-Br at different QAC loading levels and Ag. Such studies are to be performed in order to predict antimicrobial performance of the nanomaterials for the development of effective bactericidal carriers. Accordingly, the present work aims to obtain and characterize different loaded MMT/HDTMA and the respective MMT/HDTMA/Ag materials. XPS and zeta potential results were presented and discussed in order to elucidate clays structure relationship with the antimicrobial activity against Staphylococcus aureus ATCC 25923 and Escherichia coli ATCC 25922.

\section{Experimental}

\section{Materials}

The clay mineral used was a raw Argentinean montmorillonite (MMT) (Castiglioni Pes y Cia. Lago Pellegrini, Río Negro, Argentina), with a structural formula [( $\left.\left(\mathrm{Si}_{3.89} \mathrm{Al}_{0.11}\right)\left(\mathrm{Al}_{1.43} \mathrm{Fe}_{0.26} \mathrm{Mg}_{0.30}\right) \mathrm{O}_{10}(\mathrm{OH})_{2}\right]$ $\mathrm{Na}_{0.47} \mathrm{Ca}_{0.08} \mathrm{~K}_{0.02},{ }^{18}$, having a cation exchange capacity (CEC) of $0.825 \mathrm{meq} \mathrm{g}^{-1}$ and specific surface area of 39.0 $\mathrm{m}^{2} \mathrm{~g}^{-1} 19$.

Hexadecyltrimethylammonium bromide (HDTMA-Br) and precursor $\mathrm{AgNO}_{3}$ were purchased from Sigma Aldrich Co (Saint Louis, Missouri, USA).

Staphylococcus aureus ATCC 25923 (gram-positive) and Escherichia coli ATCC 25922 (gramnegative), obtained from ATCC (The American Type Culture Collection, Manassas, Virginia, USA), were grown in Mueller Hinton Broth (Britania Laboratories, Buenos Aires, Argentina) at $37^{\circ} \mathrm{C}$ for $16 \mathrm{~h}$. Until use, all strains were maintained and stored at $-20^{\circ} \mathrm{C}$ in $0.15 \mathrm{~g} / \mathrm{ml}$ of glycerol (Cicarelli, Buenos Aires, Argentina).

\section{Preparation of organo-montmorillonite and organo-montmorillonite-Ag}

Raw MMT (30 g) was dispersed in $2 \mathrm{~L}$ of deionized water and stirred at $60^{\circ} \mathrm{C}$. Amounts of HDTMA-Br corresponding to $0.5,1$, or $2 \mathrm{CEC}$ of MMT were slowly added. The mixtures were stirred for $2 \mathrm{~h}$ at $60^{\circ} \mathrm{C}$. At the end of the reaction, the products were centrifuged $(2,200 \mathrm{~g})$ and the sediments were washed to free of bromide anions (tested by $\mathrm{AgNO}_{3}$ ). The HDTMA-MMT products or organo-montmorillonite (OMMT) samples (referred to as $\mathrm{MH} 0.5, \mathrm{MH} 1$, and $\mathrm{MH} 2$, respectively) were dried overnight at $80^{\circ} \mathrm{C}$.

To attain montmorillonite-Ag (MMT-Ag) and organo-montmorillonite-Ag (OMMT-Ag) products, 0.5 $\mathrm{g}$ of raw MMT and the corresponding OMMT samples were dispersed in $25 \mathrm{ml}$ of $\mathrm{AgNO}_{3}$ solution $(0.1 \mathrm{~N})$ 
and stirred for $2 \mathrm{~h}$ at room temperature. The products obtained were washed and dried as described above; and labeled as MMT-Ag, MH0.5-Ag, MH1-Ag, and MH2-Ag.

\section{Characterization}

\section{X-ray photoelectron spectroscopy (XPS)}

XPS analyses were performed on a Physical Electronics PHI 5000 VersaProbe II spectrometer (Chanhassen, Minnesota, USA) with monochromatic Al $\mathrm{K}_{\alpha}$ radiation $(25 \mathrm{~W}, 15 \mathrm{kV}, 1486.6 \mathrm{eV})$.

The sample powders were pressed into small stainless steel troughs of $4 \mathrm{~mm}$ inner diameter and $0.5 \mathrm{~mm}$ depth, mounted on a multispecimen holder. The pressure in the analysis chamber was around $10^{-7}$ $\mathrm{Pa}$. The following sequence of spectra was recorded: survey spectrum, $\mathrm{C}_{1 \mathrm{~s}} ; \mathrm{O}_{1 \mathrm{~s}} ; \mathrm{Na}_{1 \mathrm{~s}} ; \mathrm{Mg}_{2 \mathrm{p}} ; \mathrm{Al}_{2 \mathrm{p}} ; \mathrm{Si}_{2 \mathrm{p}} ; \mathrm{Ca}_{2 \mathrm{p}}$; $\mathrm{K}_{2 \mathrm{p}} ; \mathrm{Fe}_{2 \mathrm{p}} ; \mathrm{Ag}_{3 \mathrm{~d}}$, and $\mathrm{C}_{1 \mathrm{~s}}$ again to check for charge stability as a function of time and the absence of sample degradation during the analyses. The $\mathrm{C}-(\mathrm{C}, \mathrm{H})$ component of the $\mathrm{C}_{1 \mathrm{~s}}$ peak of carbon was fixed at 284.8 $\mathrm{eV}$ to set the binding energy scale.

The rate applied to correct the charging effect was between 2.0 and $2.6 \mathrm{eV}^{20}$. Binding energies (BE) were determined with an accuracy of $0.1 \mathrm{eV}$. Analysis software PHI ACCESS ESCA-V6.0 F (Chanhassen, Minnesota, USA) was used for data acquisition and element quantification was based on survey spectra determined at four different positions of each sample, following the method detailed in the literature ${ }^{21}$. The angle between the normal to the sample surface and the direction of photoelectrons collection was about $0^{\circ}$, the resulting analyzed area was $700 \mu \mathrm{m} \times 300 \mu \mathrm{m}$. The pass energy was set at $187.85 \mathrm{eV}$ for the wide scan and 40 $\mathrm{eV}$ for narrow scans. In the later conditions, the full width at half maximum (FWHM) of the $\mathrm{Ag}_{3 \mathrm{~d} 5 / 2}$ peak of a standard silver sample was about $0.9 \mathrm{eV}$. Molar fractions were calculated using peak areas normalized on the basis of acquisition parameters after a linear background subtraction, experimental sensitivity factors and transmission factors were provided by the manufacturer. Elemental mole fractions were provided, excluding hydrogen which is not detected by XPS. The spectra decomposition was done using a Gaussian function, after subtraction of the linear baseline, and particularly a maximal $\mathrm{FWHM}=2$ were used for $\mathrm{C}_{1 \mathrm{~s}}$ decomposition. The goodness of all fits was followed by the chi-square $\left(\chi^{2}\right)$ values, which were always below 2.00. A time period of 10 min was utilized for $\mathrm{Ag}_{3 \mathrm{~d}}$ analysis to prevent the photoreduction of $\mathrm{Ag}^{+}$species.

\section{Zeta potential measurements}

Electrophoretic mobility was determined in water dispersions of the respective samples by micro electrophoresis (zeta potential function) using a Brookhaven 90Plus/Bi-MAS Multi Angle Particle Sizing (Brookhaven Instruments Corporation, New York, USA), operated at: $\lambda=635 \mathrm{~nm}, 15 \mathrm{~mW}$ solid state laser, scattering angle $=90^{\circ}$, temperature $=25^{\circ} \mathrm{C}$, and employing $10^{-3} \mathrm{M} \mathrm{KCl}$ as inert electrolyte and Pd electrodes.

\section{Antimicrobial activity by zone of inhibition assay (ZIA)}

The qualitative assay reported by Negi et al. ${ }^{14}$ with some modifications was used to detect the primary antimicrobial activity of clays. Clay powders (about $29 \pm 6 \mathrm{mg}$ ) were suspended in water, deposited on blank paper disks (diameter $6.64 \mathrm{~mm}$ ) and allowed to dry. The disks containing clays, as well as a positive control of inhibition (disk containing $50 \mu \mathrm{g}$ of chloramphenicol, Sigma Aldrich Co, Saint Louis, Missouri, USA), were placed in Mueller Hinton agar plates inoculated separately with $10^{7}$ colony-forming units (CFU) of $S$. aureus ATCC 25923 and E. coli ATCC 25922 and incubated at $37^{\circ} \mathrm{C}$ for $24 \mathrm{~h}$. Antimicrobial activity was evidenced as an inhibition zone after incubation. Each determination was performed in three independent triplicates $(9$ times).

\section{Minimum inhibitory bactericidal concentration (MBC) determination}

To examine the clays and HDMTA-Br concentrations leading to a bactericidal effect on S. aureus and E. coli, a method similar to that reported by Sondi and Salopek-Sondi ${ }^{22}$ was used. Approximately $10^{5} \mathrm{CFU} / \mathrm{ml}$ of each strain were cultured in Mueller Hinton agar plates supplemented with clays or HDTMA-Br, respectively, in concentrations of 0.15 to $200 \mathrm{mg} / \mathrm{ml}$; or 0.0003 to $0.3 \mathrm{mg} / \mathrm{ml}$. Clay-free Mueller Hinton plates cultured under the same conditions were used as negative inhibition controls. The plates were incubated for 24 
$\mathrm{h}$ at $37^{\circ} \mathrm{C} . \mathrm{MBC}$ values were defined as the lowest concentration of the tested samples from which the absence of growth was recorded.

\section{Results and Discussion}

\section{Modified clays characterization}

The proportion of elemental atomic concentrations in MMT, MMT-Ag, OMMT samples and the resultant silver clays (OMMT-Ag) deduced from the corresponding XPS analyses are summarized in Table 1.

The $\mathrm{C}_{1 \mathrm{~s}} / \mathrm{Si}_{2 \mathrm{p}}$ ratio calculated for each sample started at 0.43 for the MMT sample with zero surfactant, in agreement with previous XPS analysis of the same sample ${ }^{23}$, and increased with the surfactant loading, to 1.85, 2.42 and 3.55 for MH0.5, MH1 and MH2 samples, respectively. The $\mathrm{C}_{1 \mathrm{~s}} / \mathrm{Si}_{2 \mathrm{p}}$ ratio was 0.60 for MMT-Ag sample, and further addition of $\mathrm{Ag}^{+}$to OMMT samples generated an increase to 1.55, 2.14 and 3.08 for MH0.5$\mathrm{Ag}$, MH1-Ag, and MH2-Ag samples, respectively. The lower $\mathrm{C}_{1 \mathrm{~s}} / \mathrm{Si}_{2 \mathrm{p}}$ ratio values obtained for OMMT-Ag samples respect to the corresponding OMMT samples indicated the competition of $\mathrm{Ag}^{+}$with the surfactant for the external surface sites and/or a surface coverage of the OMMT by $\mathrm{Ag}^{+}$.

Table 1. Atomic proportion (molar fractions in \%) of each element obtained for the indicated samples.

\begin{tabular}{|c|c|c|c|c|c|c|c|c|}
\hline & MMT & MMT-Ag & MH0.5 & MH1 & MH2 & $\begin{array}{l}\text { MH0.5- } \\
\text { Ag }\end{array}$ & $\begin{array}{l}\text { MH1- } \\
\text { Ag }\end{array}$ & $\begin{array}{l}\text { MH2- } \\
\text { Ag }\end{array}$ \\
\hline $\mathrm{C}_{1 s}$ & $\begin{array}{l}8.83 \\
\pm 0.85 \\
\end{array}$ & $\begin{array}{l}12.23 \\
\pm 0.76 \\
\end{array}$ & $\begin{array}{l}29.36 \\
\pm 3.27 \\
\end{array}$ & $\begin{array}{l}35.62 \\
\pm 2.31 \\
\end{array}$ & $\begin{array}{l}46.74 \\
\pm 3.62 \\
\end{array}$ & $\begin{array}{l}25.74 \\
\pm 4.72 \\
\end{array}$ & $\begin{array}{l}32.28 \\
\pm 2.58 \\
\end{array}$ & $\begin{array}{ll}40.99 & \pm \\
6.42 & \\
\end{array}$ \\
\hline $\mathbf{N}_{l s}$ & 0 & 0 & $\begin{array}{l}0.82 \\
\pm 0.52\end{array}$ & $\begin{array}{l}0.79 \\
\pm 0.23\end{array}$ & $\begin{array}{l}1.45 \\
\pm 1.22\end{array}$ & $\begin{array}{l}1.67 \\
\pm 0.40\end{array}$ & $\begin{array}{l}1.98 \\
\pm 0.61\end{array}$ & $\begin{array}{l}2.68 \\
\pm 0.42\end{array}$ \\
\hline $\mathrm{O}_{l s}$ & $\begin{array}{l}57.50 \\
\pm 3.95 \\
\end{array}$ & $\begin{array}{l}56.30 \\
\pm 3.88 \\
\end{array}$ & $\begin{array}{l}46.61 \\
\pm 2.67 \\
\end{array}$ & $\begin{array}{l}42.18 \\
\pm 3.09 \\
\end{array}$ & $\begin{array}{l}32.82 \\
\pm 2.88 \\
\end{array}$ & $\begin{array}{l}48.07 \\
\pm 3.91 \\
\end{array}$ & $\begin{array}{l}44.97 \\
\pm 0.97 \\
\end{array}$ & $\begin{array}{l}36.98 \pm \\
4.42\end{array}$ \\
\hline $\mathrm{Na}_{l s}$ & $\begin{array}{l}1.66 \\
\pm 0.05\end{array}$ & $\begin{array}{l}0.06 \\
\pm 0.09\end{array}$ & $\begin{array}{l}0.12 \\
\pm 0.05\end{array}$ & $\begin{array}{l}0.10 \\
\pm 0.06\end{array}$ & $\begin{array}{l}0.09 \\
\pm 0.07\end{array}$ & $\begin{array}{l}0.10 \\
\pm 0.09\end{array}$ & $\begin{array}{l}0.09 \\
\pm 0.09\end{array}$ & $\begin{array}{l}0.06 \\
\pm 0.06\end{array}$ \\
\hline $\mathrm{Ca}_{2 p}$ & $\begin{array}{l}0.44 \\
\pm 0.07\end{array}$ & 0 & $\begin{array}{l}0.09 \\
\pm 0.06\end{array}$ & $\begin{array}{l}0.07 \\
\pm 0.05\end{array}$ & $\begin{array}{l}0.07 \\
\pm 0.07\end{array}$ & $\begin{array}{l}0.06 \\
\pm 0.06\end{array}$ & $\begin{array}{l}0.05 \\
\pm 0.03\end{array}$ & $\begin{array}{l}0.06 \\
\pm 0.09\end{array}$ \\
\hline $\mathrm{K}_{2 p}$ & $\begin{array}{l}0.27 \\
\pm 0.10\end{array}$ & 0 & $\begin{array}{l}0.07 \\
\pm 0.07\end{array}$ & $\begin{array}{l}0.04 \\
\pm 0.09\end{array}$ & $\begin{array}{l}0.05 \\
\pm 0.07\end{array}$ & $\begin{array}{l}0.06 \\
\pm 0.10\end{array}$ & $\begin{array}{l}0.04 \\
\pm 0.05\end{array}$ & $\begin{array}{l}0.05 \\
\pm 0.06\end{array}$ \\
\hline $\mathrm{Mg}_{2 p}$ & $\begin{array}{l}1.86 \\
\pm 0.24 \\
\end{array}$ & $\begin{array}{l}2.10 \\
\pm 0.98 \\
\end{array}$ & $\begin{array}{l}0.71 \\
\pm 0.58 \\
\end{array}$ & $\begin{array}{l}0.61 \\
\pm 0.36 \\
\end{array}$ & $\begin{array}{l}0.52 \\
\pm 0.70 \\
\end{array}$ & $\begin{array}{l}0.49 \\
\pm 0.22 \\
\end{array}$ & $\begin{array}{l}0.35 \\
\pm 0.29 \\
\end{array}$ & $\begin{array}{l}0.44 \\
\pm 0.11 \\
\end{array}$ \\
\hline $\mathrm{Al}_{2 p}$ & $\begin{array}{l}8.47 \\
\pm 0.78\end{array}$ & $\begin{array}{l}7.56 \\
\pm 1.01\end{array}$ & $\begin{array}{l}5.94 \\
\pm 0.88\end{array}$ & $\begin{array}{l}5.62 \\
\pm 1.02\end{array}$ & $\begin{array}{l}4.83 \\
\pm 0.64\end{array}$ & $\begin{array}{l}6.59 \\
\pm 1.29\end{array}$ & $\begin{array}{l}4.73 \\
\pm 0.76\end{array}$ & $\begin{array}{l}4.05 \\
\pm 0.66\end{array}$ \\
\hline $\mathrm{Si}_{2 \mathrm{p}}$ & $\begin{array}{l}20.38 \\
\pm 0.65\end{array}$ & $\begin{array}{l}20.24 \\
\pm 0.78\end{array}$ & $\begin{array}{l}15.86 \\
\pm 0.85\end{array}$ & $\begin{array}{l}14.69 \\
\pm 0.77\end{array}$ & $\begin{array}{l}13.16 \\
\pm 0.57\end{array}$ & $\begin{array}{l}16.59 \\
\pm 0.94\end{array}$ & $\begin{array}{l}15.08 \\
\pm 1.19\end{array}$ & $\begin{array}{l}13.30 \quad \pm \\
1.49\end{array}$ \\
\hline $\mathrm{Fe}_{2 p}$ & $\begin{array}{l}0.62 \\
\pm 0.12\end{array}$ & $\begin{array}{l}0.55 \\
\pm 0.15\end{array}$ & $\begin{array}{l}0.36 \\
\pm 0.08\end{array}$ & $\begin{array}{l}0.30 \\
\pm 0.06\end{array}$ & $\begin{array}{c}0.25 \\
\pm 0.08\end{array}$ & $\begin{array}{l}0.25 \\
\pm 0.20\end{array}$ & $\begin{array}{l}0.18 \\
\pm 0.14\end{array}$ & $\begin{array}{l}0.18 \\
\pm 0.16\end{array}$ \\
\hline $\mathrm{Ag}_{3 d}$ & 0 & $\begin{array}{ll}0.96 & \pm \\
0.17 & \end{array}$ & 0 & 0 & 0 & $\begin{array}{l}0.40 \\
\pm 0.06\end{array}$ & $\begin{array}{l}0.09 \\
\pm 0.07\end{array}$ & $\begin{array}{l}0.10 \\
\pm 0.05\end{array}$ \\
\hline $\mathrm{Br}_{3 d}$ & 0 & 0 & 0 & 0 & 0 & 0 & 0 & $\begin{array}{l}0.99 \\
\pm 0.32\end{array}$ \\
\hline Total & 100.03 & 100.00 & 99.94 & 100.02 & 99.98 & 100.00 & 99.84 & 99.88 \\
\hline $\mathrm{Ag}_{3 d} / \mathrm{Al}_{2 p}$ & 0 & 0.13 & 0 & 0 & 0 & 0.06 & 0.02 & 0.03 \\
\hline $\mathrm{Ag}^{0} / \mathrm{Al}_{2 p}$ & 0 & 0.06 & 0 & 0 & 0 & 0.03 & 0.02 & 0.01 \\
\hline $\begin{array}{l}\mathrm{Ag}^{+}{ }_{(\mathrm{AgBr})} / \\
\mathrm{Al}_{2 p}\end{array}$ & 0 & 0 & 0 & 0 & 0 & 0 & 0 & 0.01 \\
\hline $\begin{array}{l}\mathrm{Ag}^{\text {(cluster) }}{ }_{3} \\
69 \mathrm{eV} / \mathrm{Al}_{2 p}\end{array}$ & 0 & 0.07 & 0 & 0 & 0 & 0.03 & 0 & 0 \\
\hline $\begin{array}{l}\mathrm{Ag}^{+}(\mathrm{AgBr}) \\
\mathrm{Ag}^{0}\end{array}$ & 0 & 0 & 0 & 0 & 0 & 0 & 0 & 1.50 \\
\hline $\mathrm{Br}_{3 \mathrm{~d}} / \mathrm{Al}_{2 p}$ & 0 & 0 & 0 & 0 & 0 & 0 & 0 & 0.22 \\
\hline
\end{tabular}


The MMT-Ag sample showed a little amount of interlayer remaining $\mathrm{Na}^{+}$(Table 1) with a ratio of the molar fraction $\mathrm{Ag}_{3 \mathrm{~d}} / \mathrm{Na}_{1 \mathrm{~s}}=16$. This high molar fraction could be associated to the presence of both cations at the MMT interlayer, and some $\mathrm{Ag}^{+}$presence also on the external MMT surface. Sodium and Calcium were replaced according to the surfactant loading in OMMT ${ }^{21}$ and OMMT-Ag samples, whereas Potassium was replaced irrespective of the surfactant loading.

$\mathrm{Mg}$ and $\mathrm{Fe}$ were detected in similar amounts within the error values at MMT and MMT-Ag samples, present mainly as isomorphic substitutions in the octahedral layer of the montmorillonite. The $\mathrm{Mg}$ and $\mathrm{Fe}$ amounts decrease, as those for $\mathrm{Si}$ and $\mathrm{Al}$ (Table 1), with the surfactant loading for OMMT samples indicated an increase of surfactant coating of the montmorillonite external surface. The $\mathrm{Ag}^{+}$addition to OMMT samples generated a subsequent decrease of $\mathrm{Mg}$ and $\mathrm{Fe}$ amounts, or $\mathrm{Mg} / \mathrm{Si}$ and $\mathrm{Fe} / \mathrm{Si}$ ratio (Online Resource 1), pointing out the OMMT surface coverage by $\mathrm{Ag}^{+}$.

The $\mathrm{Ag}_{3 \mathrm{~d}} / \mathrm{Al}_{2 \mathrm{p}}$ ratio calculated for all OMMT-Ag samples (Table 1) indicated a decrease of $\mathrm{Ag}$ with the increase of surfactant loading.

The thermogravimetric analysis (TG), from 180 to $800^{\circ} \mathrm{C}$, of same OMMT samples was performed in a previous work ${ }^{24}$, and the actual HDTMA ${ }^{+}$loadings obtained were $0.49,0.90$, and $1.62 \mathrm{meq} / \mathrm{g}$ clay, respectively for MH0.5, MH1 and MH2 samples. Taking these values, a calculation was performed to link the experimentally determined atomic proportions (XPS) to the actual loadings of $\mathrm{HDTMA}^{+}$. The molar ratios C/Si obtained from TG data were: $0.90,1.66$, and 2.99 respectively for MH0.5, MH1, and MH2 samples. The difference between $\mathrm{C} / \mathrm{Si}$ ratios obtained by XPS and TG, were in agreement with previous data obtained by comparing the XPS area of nitrogen with TG data ${ }^{24}$. In the afore mentioned work, the lower percentage of adsorbed surfactant determined by XPS than that obtained by TG data was assigned to the different evaluation of the Van der Waals interactions of the surfactant with MMT surface between both techniques. As a consequence, the actual loading amount of HDTMA for OMMT calculated by XPS data would be a subevaluation.

Quaternary ammonium (HDTMA-Br) and Ag oxidation changes due to adsorption on solid surfaces were determined through the binding energy (BE) shift by X-ray photoelectron spectroscopy analyses (Figs. 1 to 4). Table 2 resumes the position of peak maximum, FWHM and $\chi^{2}$ of C-C and C-N bonds, obtained from deconvolution of the $\mathrm{C}_{1 \mathrm{~s}}$ peaks for all samples.

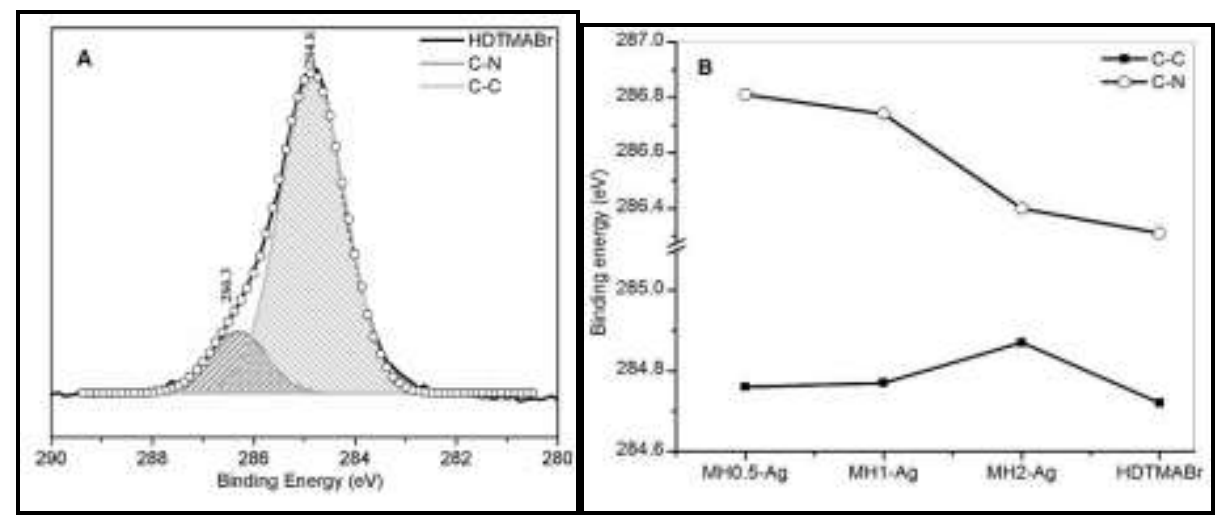

Figure 1 - A. C1s XPS spectrum of HDTMABr. B. C1s binding energies of indicated samples

Table 2. Position of peak maximum, standard deviation, FWHM and $\chi^{2}$ of C-C and C-N bonds, obtained from deconvolution of the $\mathrm{C}_{1 \mathrm{~s}}$ peak for all samples

\begin{tabular}{|l|l|l|l|l|l|l|l|}
\hline Sample & C-C & Std. dev. & FWHM & C-N & Std. dev. & FWHM & $\dot{\div}^{\mathbf{2}}$ \\
\hline MH0.5 & 284.76 & 0.05 & 1.63 & 286.50 & 0.13 & 2.26 & 1.30 \\
\hline MH1 & 284.83 & 0.07 & 1.70 & 286.63 & 0.11 & 1.47 & 1.38 \\
\hline MH2 & 284.82 & 0.09 & 1.93 & 285.74 & 0.29 & 1.30 & 1.42 \\
\hline MH0.5-Ag & 284.77 & 0.07 & 1.57 & 286.81 & 0.10 & 1.92 & 1.07 \\
\hline MH1-Ag & 284.87 & 0.10 & 1.50 & 286.74 & 0.20 & 1.67 & 1.58 \\
\hline MH2-Ag & 284.72 & 0.02 & 1.54 & 286.40 & 0.12 & 1.29 & 1.64 \\
\hline
\end{tabular}


Particularly, the $\mathrm{C}_{1 \mathrm{~s}}$ spectra for HDTMA-Br (Fig. 1A), OMMT and OMMT-Ag samples (Table 2, and Fig. 1B) exhibited two peaks at around 284.8 and $286.3 \mathrm{eV}$, corresponding to $\mathrm{C}-\mathrm{C}$ and $\mathrm{C}-\mathrm{N}$ bonds, respectively ${ }^{25}$. For OMMT samples the BE of $\mathrm{C}-\mathrm{C}$ bonds were within $0.04 \mathrm{eV}$ respect to that of HDTMA-Br, whereas for $\mathrm{BE}$ of $\mathrm{C}-\mathrm{N}$ bonds a stronger difference of $0.44 \mathrm{eV}$ was found ${ }^{21,24}$.

For OMMT-Ag samples the $\mathrm{C}_{1 \mathrm{~s}}$ spectrum corresponding to $\mathrm{C}-\mathrm{C}$ varied within $0.15 \mathrm{eV}$ respect to that of HDTMA-Br, in agreement with data found by Schampera et al. ${ }^{21}$ for OMMT with same surfactant. The C-N peak of HDTMA-Br sample at $286.3 \mathrm{eV}$, shifted to higher BE for MH0.5-Ag and MH1-Ag samples (286.8 and $286.7 \mathrm{eV}$, respectively); whereas that of MH2-Ag sample presented a BE value similar to that of HDMTA-Br (Table 2, Fig. 1B). The shift of C-N peaks for OMMT-Ag samples towards higher BE could be associated with a change in chemical environment due to electrostatic interaction between the ammonium group (positive charge) and the MMT-Ag surface (more negatively charged than the respective MMT sample). The differences found in $\mathrm{BE}$ of the $\mathrm{C}_{1 \mathrm{~s}}$ with the increase of surfactant loading was assigned to the more complex arrangement of HDTMA and changes in the local bonding environment of the aliphatic chains ${ }^{21}$, which seemed not to change with the $\mathrm{Ag}^{+}$presence (Table 2).

The $\mathrm{N}_{1 \mathrm{~s}}$ peaks presence in OMMT samples was previously evaluated by our work group ${ }^{24}$. The $\mathrm{N}_{1 \mathrm{~s}}$ peaks from HDTMA-Br and MH0.5-Ag samples; and the BE values obtained for all OMMT-Ag samples are shown in Figures 2A, 2B, and 2C, respectively.

Particularly, when the quaternary ammonium interacted with the clay in $\mathrm{Ag}$ presence $(\mathrm{MH} 0.5-\mathrm{Ag}$ sample), this peak shifted to $403.1 \mathrm{eV}$, and a second smooth and broad peak of $\mathrm{N}_{1 \mathrm{~s}}$ appeared at $401.2 \mathrm{eV}$ (Fig. $2 \mathrm{~B})^{26}$, with a fit of the peaks to $\mathrm{N}_{1 \mathrm{~s}}$ profile of $\chi^{2}=1.20$. Both peaks were also found for MH1-Ag and MH2-Ag samples (Fig. 2C), appearing at lower BE (402.9 and $400.5 \mathrm{eV} ; 402.6$ and $399.5 \mathrm{eV}$, for MH1-Ag and MH2-Ag samples, with a fit of the peaks to $\mathrm{N}_{1 \mathrm{~s}}$ profile of $\chi^{2}=1.88$ and 1.41 , respectively).

The symmetrical peak of $\mathrm{N}_{1 \mathrm{~s}}$ spectrum at $402.3 \mathrm{eV}$ (Fig. 2A), observed in HDTMA-Br, indicated only one chemical status for nitrogen in the surfactant molecule ${ }^{24,27}$. However, the smooth broadening of the $\mathrm{N}_{1 \mathrm{~s}}$ peak present in all OMMT-Ag samples (Fig. 2B) could be attributed to two different transitions, the first occurring around $403 \mathrm{eV}$ and the second between 399.5 and $401 \mathrm{eV}$.

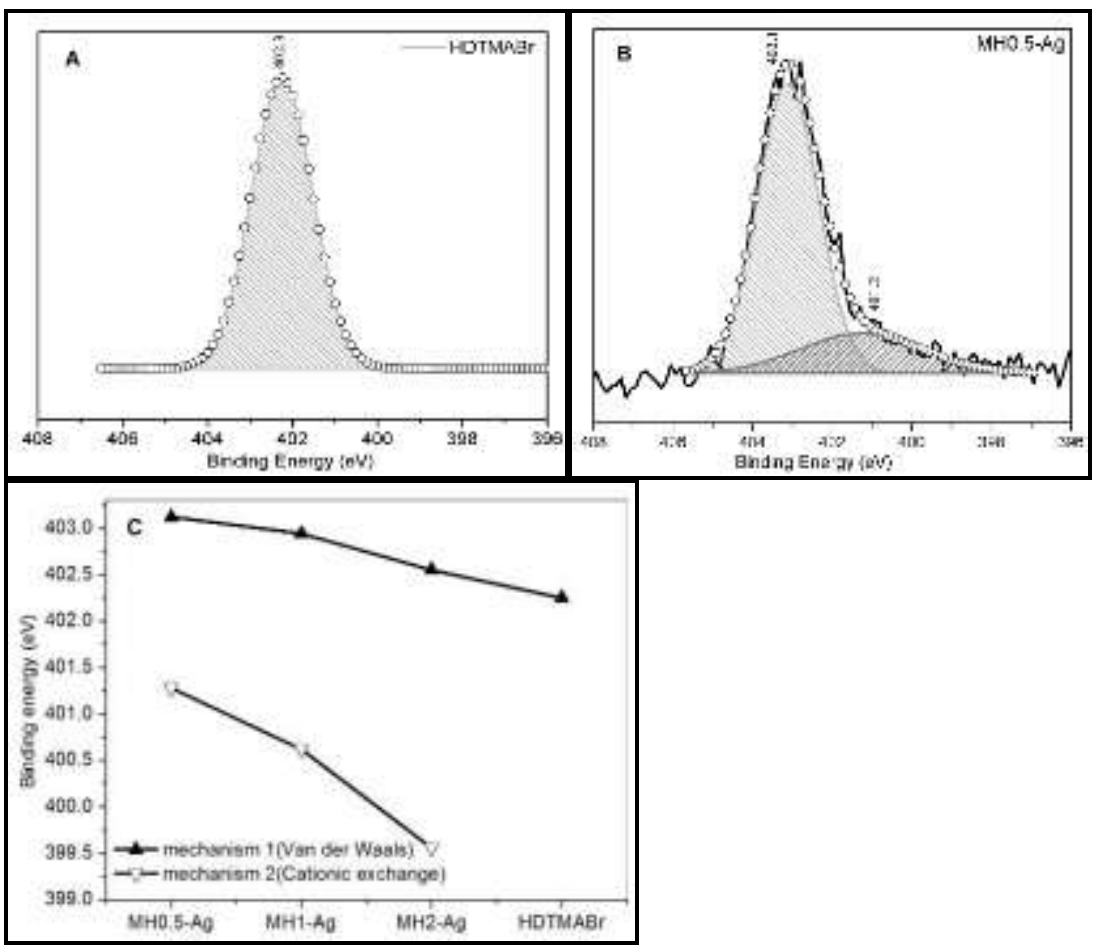

Figure 2 - N1s high-resolution XPS spectra of A. HDTMABr and B. MH0.5-Ag sample. C. N1s binding energies of OMMT-Ag samples 
The position of the bands around $403 \mathrm{eV}$, which coincided with the BE range of the quaternary nitrogen $\mathrm{N}_{1 \mathrm{~s}}$ band (Fig. 2B), could be assigned to nitrogen atoms of the surfactant molecules adsorbed on the surface with low energy through Van der Waals interactions (mechanism 1: surfactant molecules interaction with that previously adsorbed on the clay by the strong cation-exchange mechanism) ${ }^{24}$ (Fig. 2C). The interaction between the positive head of HDTMA alkyl group and the clay surface shifted $\mathrm{N}_{1 \mathrm{~s}}$ peak from $402.3 \mathrm{eV}$ towards higher BE, reaching 403.1 and 402.9 for $\mathrm{MH} 0.5-\mathrm{Ag}$ and $\mathrm{MH1}-\mathrm{Ag}$ samples, respectively (Fig. 2C). Nevertheless, for MH2-Ag sample the shift was close to that of the surfactant itself $(402.6 \mathrm{eV})$, indicating a local environment of nitrogen similar to that observed for the surfactant in bulk state, which was previously reported for HDMTA-Br load exceeding the CEC ${ }^{24}$.

Besides, the position of the $\mathrm{N}_{1 \mathrm{~s}}$ bands between 399.5 and $401 \mathrm{eV}$ (Fig. 2B) has previously been attributed to adsorption through cation exchange (mechanism 2) based on XPS studies, and as was earlier reported for HDTMA-MMT ${ }^{24}$. The BE value decrease for the second $\mathrm{N}_{1 \mathrm{~s}}$ peak was assigned to an increase in electron density on the nitrogen atom due to a charge transfer from the clay sheets (Fig. 2C) ${ }^{24,28}$. This analysis was in agreement with the $\mathrm{C}_{1 \mathrm{~s}}$ spectra of $\mathrm{C}-\mathrm{N}$ bonds (Fig. 1B).

The absence of $\mathrm{Br}_{3 \mathrm{~d}}$ in $\mathrm{MH0.5}$ and $\mathrm{MH} 1$ samples (Table 1) and the respective $\mathrm{Ag}^{+}$loaded OMMT samples, indicated that this element was eliminated completely by the washing procedure performed to these samples, in agreement with previous data ${ }^{24}$. Whilst in $\mathrm{MH} 2$ sample $\mathrm{Br}_{3 \mathrm{~d}}$ spectrum associated with $\mathrm{Br}^{-}$ presence was not observed, in MH2-Ag sample an amount of $0.99 \%$ was found (Table 1). In Figure 3 the $\mathrm{Br}_{3 \mathrm{~d}}$ spectra from HDTMA-Br and MH2-Ag samples are shown. Particularly, the $\mathrm{Br}_{3 \mathrm{~d}}$ spectrum of $\mathrm{HDTMA}-\mathrm{Br}$ showed the presence of two peaks at 68.3 and $67.4 \mathrm{eV}$ corresponding to the $\mathrm{BE}$ of $\mathrm{Br}_{3 \mathrm{~d} 3 / 2}$ and $\mathrm{Br}_{3 \mathrm{~d}}$ /2, respectively, and keeping a peaks adjustment to the $\mathrm{Br}_{3 \mathrm{~d}}$ profile of $\chi^{2}=1.13$. MH2-Ag sample exhibited a peak at $69.3 \mathrm{eV}$ besides that located at $68.3 \mathrm{eV}$ and lower peaks fit to the $\operatorname{Br}_{3 \mathrm{~d}}$ profile $\left(\chi^{2}=1.53\right)$.

Silver can form complex with HDTMA in solution ${ }^{29}$. Moreover, loading increase of some quaternary ammonium ions onto montmorillonite surfaces affect the heavy metal adsorption ${ }^{30}$. For the present work, the absence of silver complex with HDTMA adsorbed on MMT was verified by the absence of a $1969 \mathrm{~cm}^{-1}$ IR band (Fig. not shown), whose presence evidences the effect of $\mathrm{Br}-\mathrm{Ag}$ bond on $\mathrm{CH}_{3}-\mathrm{N}^{+}$vibration ${ }^{29}$. In contrast, this peak was recorded in $\mathrm{MH} 2-\mathrm{Ag}$ sample (Fig. 3 and Fig. $4 ; \mathrm{Br}_{3 \mathrm{~d}}$ and $\mathrm{Ag}_{3 \mathrm{~d}}$ spectra, respectively), suggesting that both surfactant cations and ion pairs occurred in this sample, interacting with the clay, respectively by ion exchange and sorption through weak interaction ${ }^{24,26}$. Furthermore, the peak at $69.3 \mathrm{eV}$ besides that located at $68.3 \mathrm{eV}$, for MH2-Ag could be attributed to the crystal lattice of $\mathrm{Br}^{-}$in $\mathrm{AgBr}^{28,31}$.

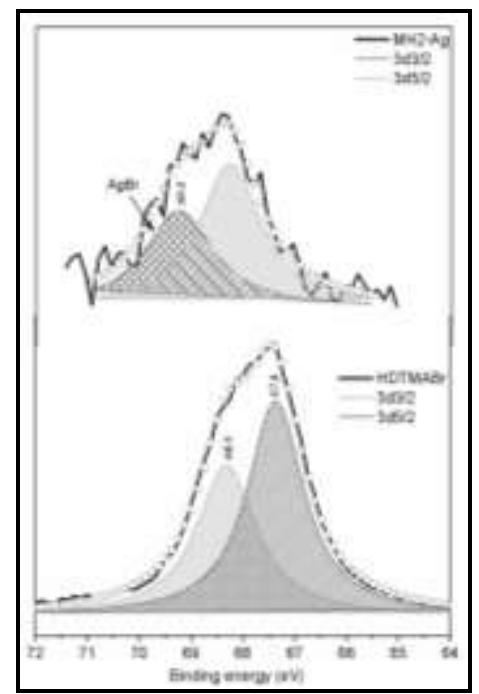

Figure 3 - Br 3d high-resolution XPS spectra of HDTMABr and MH2-Ag sample 


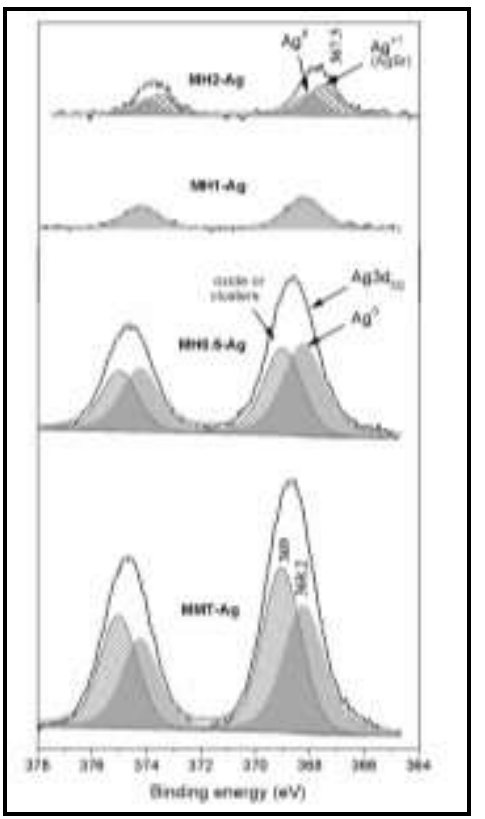

Figure 4. Ag3d high-resolution XPS spectra of OMMT-Ag and MMT-Ag samples

The $\mathrm{Ag}_{3 \mathrm{~d}}$ peaks of MMT-Ag and OMMT-Ag samples (Fig. 4) presented broad profiles that were fitted into two Gaussian components, assigned to different components. The peak at $368.2 \mathrm{eV}$ was assigned to the formation of metallic silver ${ }^{32-34}$. Meanwhile, the peak around $369 \mathrm{eV}$ could be attributed to either oxidized silver species $\left(\mathrm{Ag}_{2} \mathrm{O}\right.$ or $\left.\mathrm{AgOH}\right)$ intimately interacting with the clay surface or to metallic sub-nanoparticles associated in small clusters ${ }^{15,32,35}$.

The peak associated with metallic silver was observed in all samples. Nevertheless, that located at 369 $\mathrm{eV}$ was only evident for MMT-Ag and MH0.5-Ag samples (Fig. 4), decreasing the area ratios calculated with respect to the structural $\mathrm{Al}_{2 \mathrm{p}}$ peak from 0.07 to 0.03 , respectively (Table 1). In contrast, $\mathrm{MH} 1-\mathrm{Ag}$ sample showed only one peak associated with metallic $\mathrm{Ag}-\mathrm{Ag}\left(\mathrm{Ag}^{0}\right)$ (Fig. 4). Besides, for MH2-Ag sample a peak broadening for $\mathrm{Ag}_{3 \mathrm{~d}}$ 5/2 was observed, indicating the presence of a new peak at $367.5 \mathrm{eV}$ attributed to the formation of $\mathrm{AgBr}$, in agreement with $\mathrm{Br}_{3 \mathrm{~d}}$ spectra (Fig. 3$)^{28}$.

Based on XPS results, and the models proposed by Naranjo et al. ${ }^{24}$ and $\mathrm{He}$ et al. ${ }^{26}$, adsorption of the quaternary ammonium in OMMT-Ag at the clay interlayer by a cation-exchange mechanism (mechanism 2) through the positive head of the ammonium group could be suggested. At relative low surfactant concentration $(\leq 1 \mathrm{CEC})$, intercalation could be dominant and HDMTA-Br could enter into the clay interlayer space as cation $\left(\mathrm{HDTMA}^{+}\right.$), leading to a lateral monolayer, and a pseudotrilayer structure for MH0.5 and MH1 samples, respectively. Similarly, the prevalence of a weak adsorption mechanism leading to a paraffin bilayer structure could be suggested for MH2-Ag ${ }^{21,24,26,36}$. As will be further discussed, these results were supported by zeta potential determinations.

Zeta potential values $v s \mathrm{pH}$ were recorded for MMT, OMMT, and their Ag counterparts (Fig. 5A and $5 \mathrm{~B}$, respectively).

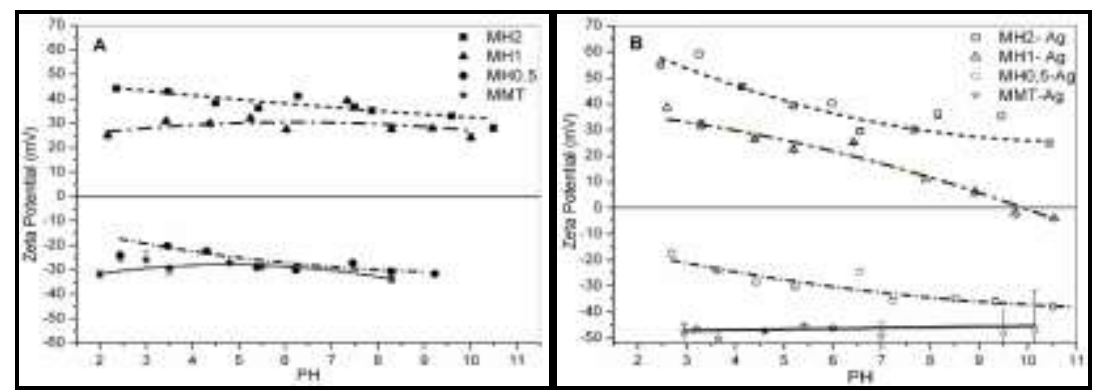

Figure 5 - Zeta potential of A. OMMT and B. OMMT-Ag samples 
The classical negative surface charge was observed for MMT sample (Fig. 5A), originated by structural isomorphic substitutions within the clay sheets ${ }^{36}$. A decrease of negative charge was found with the increase of QAC, attaining a positive charge when QAC loading was $\geqq$ CEC (Fig. 5A) ${ }^{24,37}$, indicating not only the full neutralization of the initial MMT negative charge, but also a bilayer arrangement formed by (chain-chain) hydrophobic interactions of the surfactant for MH1 and $\mathrm{MH} 2$ samples, thus producing positive charge at the external surface ${ }^{36,38}$.

The Ag exchange into MMT (Fig. 5B), caused an increase of negative charge with respect to MMT sample, in agreement with previous data ${ }^{15}$ and assigned to silver clusters or oxide formation as indicated in the $\mathrm{Ag}_{3 \mathrm{~d}}$ spectra obtained by XPS (Fig. 4). For MH0.5-Ag and MH1-Ag samples, a slight increase of negative charge and a decrease of positive charge, from $\mathrm{pH}$ around 5, were found as compared to MH0.5 and MH1 samples, respectively (Fig. 5A and B). However, for $\mathrm{MH} 2-\mathrm{Ag}$ sample the presence of $\mathrm{AgBr}$ and $\mathrm{Ag}^{0}$ nanoparticles (as indicated by XPS, Fig. 4 and 5) produced an increase of the positive zeta potential value with respect to MH2 sample, mainly up to $\mathrm{pH} 5$.

A reduction of $\mathrm{Ag}^{+}$to $\mathrm{Ag}^{0}$ or the presence of clusters or $\mathrm{Ag}_{2} \mathrm{O}$ as evidenced by XPS analysis (Fig. 4, Table 1), in agreement with that found by SEM analysis ${ }^{8}$, as well as surface coordination of hydroxylated silicon surface groups and $\mathrm{Ag}^{+37,39}$, could be responsible for the surface negative charge increase observed in MMT-Ag with respect to MMT sample. Similarly, the increase in negative charge in MH0.5-Ag (Fig. 5B) with respect to its OMMT counterpart could be attributed to the same chemical species (Fig. 5B, Table 1).

The slight increase of negative charge and the decrease in positive charge at $\mathrm{pH}$ around 5, for MH0.5$\mathrm{Ag}$ and MH1-Ag samples with respect to the same samples without Ag, could be assigned to the presence of $\mathrm{Ag}^{0}$ nanoparticles (isoelectric point, IEP $<\mathrm{pH}$ 2), in agreement with $\mathrm{Ag}_{3 \mathrm{~d}}$ XPS peak deconvolution (Fig. 4), which presented low negative zeta potential below $\mathrm{pH} 5$, increasing with $\mathrm{pH}$ up to $\mathrm{pH} 8$, where the particles were quite stable due to electrostatic repulsion ${ }^{40}$.

In MH2-Ag sample the increase in positive zeta potential value with respect to $\mathrm{MH} 2$ sample, could be assigned to the excess of cationic surfactant and the start of $\mathrm{Br}^{-}$sorption ${ }^{24}$, with the consequent $\mathrm{AgBr}$ formation, as indicated by XPS spectra (Fig. 3 and 4). Due to the IEP of $\mathrm{AgBr}$ at pH $5^{41}$; and to the presence of $\mathrm{Ag}^{0}$ nanoparticles, with IEP below $\mathrm{pH} 2^{40}$, a higher positive zeta potential value in $\mathrm{MH} 2-\mathrm{Ag}$ with respect to MH2 sample was found up to $\mathrm{pH} 5$.

\section{Relationship between structure and antimicrobial activity}

ZIA determination was performed to obtain a rapid screening of samples antimicrobial activity (Fig. 6), which was further quantified by MBC determination (Table 3).

As can be seen from the activity against $S$. aureus and E. coli, exerted by the clay and OMMT respectively (Fig. 6A and 6B), and their Ag counterparts samples (Fig. 6C and 6D), antimicrobial activity was dependent on both the clay modifier and the sensitive microorganism used.

When assayed against S. aureus (Fig. 6A and 6C), OMMT, OMMT-Ag as well as MMT-Ag samples evidenced antimicrobial activity, in contrast to MMT sample. The increase of surfactant loading augmented inhibition areas against $S$. aureus, as observed for MH0.5, MH1, and MH2 samples (Fig. 6A). Furthermore, an increase in inhibitory activity upon silver addition to the clays was only evident for MMT-Ag and MH0.5Ag samples (Fig. 6C).

OMMT samples presented limited antimicrobial activity against $E$. coli with inhibition areas being evident only for MH2 sample (Fig. 6B). In contrast, Ag addition to MMT and OMMT imparted antimicrobial activity against $E$. coli to all the samples (Fig. 6D). 


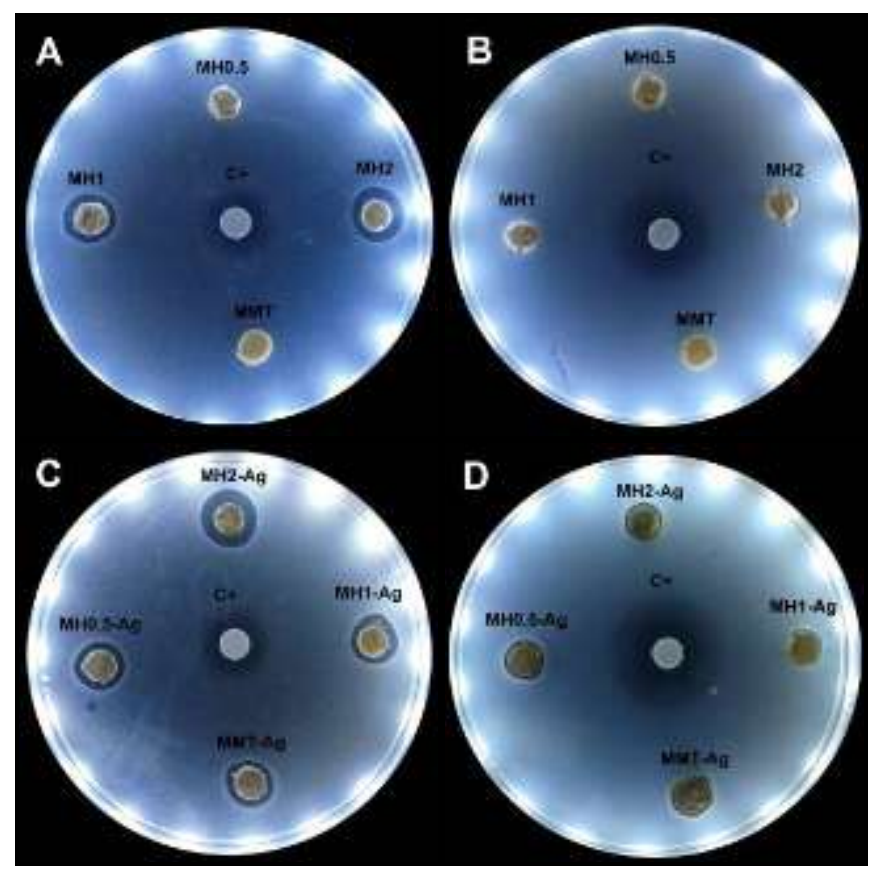

Figure 6 - Antimicrobial activity of the indicated clays against A.C. S. aureus ATCC 25923 and B.D. $E$. coli ATCC 25922. Dark zones in the agar plates indicate microorganisms grown inhibition. C+ indicates a positive inhibition control

When quantifying bactericidal activity, more concentrations of all clays were needed to kill the assayed bacteria when compared to the free surfactant (Table 3). For all OMMT samples the higher the surfactant loading, the lower the MBC. Thus, in order to kill $S$. aureus using MH0.5 sample, a concentration four times higher than that of MH1 sample and around ten times higher than that of MH2 sample was required (Table 3). Similarly, MH0.5 sample showed no ability to kill $E$. coli, whereas $50.00 \pm 21.65$ and $2.50 \pm 1.08 \mathrm{mg} / \mathrm{ml}$ were needed to kill this bacterium using MH1 and MH2 samples, respectively.

In addition, when comparing the antimicrobial activity of silver-added clays with their respective counterparts, a reduction of the MBC needed to kill S. aureus upon Ag addition was observed (Table 3). A similar effect was observed against $E$. coli for all samples except for $\mathrm{MH} 2$ sample, for which MBC was not affected by $\mathrm{Ag}$ addition ( $\mathrm{p} \geq 0.05$ ) (Table 3 ).

The behavior and properties of the organic MMT depend largely on the structure of the composites and the organic molecular/ion environment in the interlayer ${ }^{14}$. OMMT antimicrobial activity found in the present work was intimately related to the surfactant availability within the clay. Thus, the increase as well as rearrangements of $\mathrm{HDTMA}^{+}$in the clay had an effect on antimicrobial activity. For both assayed microorganisms, major antimicrobial activities were observed for $\mathrm{MH} 1$ and $\mathrm{MH}$ 2, compared to MH0.5 sample. This result could be explained in terms of van der Waals interactions (mechanism 1), which were more relevant in $\mathrm{MH} 1$ and $\mathrm{MH} 2$; whereas in $\mathrm{MH} 0.5$ sample the surfactant mainly interacted by cation exchange (mechanism 2), as previously discussed. Weak interactions could allow $\mathrm{HDTMA}^{+}$to be easily released from the clay to reach the cell membranes in a concentration higher than the minimum inhibitory concentration (MIC), thus giving the observed inhibitory activities (Fig. 6A and 6B) ${ }^{42}$. This behavior was reflected in the reduction of clay concentration needed to kill bacteria when HDMTA $^{+}$loaded concentration increased over the CEC as studied by MBC assays (Table 3). Moreover having the highest proportion of HDMTA-Br and van der Waals interactions, as calculated from XPS (Table 1), MH2 showed the highest bactericidal capacity with respect to the other OMMT samples. Similarly, Parolo et al. ${ }^{43}$ found that only smectites exchanged with an amount of surfactant greater than that of the mineral CEC exhibited suitable antibacterial activity against $E$. coli, attributing the inhibition effect to the surfactant from the external clay surface. 
Table 3. Antimicrobial activity of the indicated samples, expressed as minimum bactericidal concentration (MBC) against S. aureus and E.coli

\begin{tabular}{|l|l|l|}
\hline \multirow{2}{*}{ Sample } & \multicolumn{2}{|l|}{ MBC $(\mathbf{m g} / \mathbf{m l})$ against } \\
\cline { 2 - 3 } & S. aureus ATCC 25923 & E. coli ATCC 25922 \\
\hline MMT & ND & ND \\
\hline MH0.5 & $5.56 \pm 2.73^{\mathrm{a}}$ & ND \\
\hline MH1 & $1.33 \pm 0.66^{\mathrm{b}}$ & $50.00 \pm 21.65^{\mathrm{a}}$ \\
\hline MH2 & $0.50 \pm 0.15^{\mathrm{c}}$ & $2.50 \pm 1.08^{\mathrm{b}}$ \\
\hline HDTMABr & $0.0067 \pm 0.0034^{\mathrm{d}}$ & $0.042 \pm 0.016^{\mathrm{c}}$ \\
\hline MMT-Ag & $5.00 \pm 2.17^{\mathrm{a}}$ & $0.83 \pm 0.31^{\mathrm{d}}$ \\
\hline MH0.5-Ag & $0.57 \pm 0.28^{\mathrm{c}}$ & $11.11 \pm 5.46^{\mathrm{e}}$ \\
\hline MH1-Ag & $0.67 \pm 0.33^{\mathrm{c}}$ & $1.04 \pm 0.31^{\mathrm{d}}$ \\
\hline MH2-Ag & $0.28 \pm 0.14^{\mathrm{f}}$ & $3.75 \pm 1.62^{\mathrm{b}}$ \\
\hline
\end{tabular}

ND, bactericidal activity not detected; MMT, montmorillonite; MH0.5, MH1, and MH2 are MMT loaded with HDTMABr corresponding to $0.5,1$, or $2 \mathrm{CEC}$, respectively; MMT-Ag, MH0.5-Ag, MH1-Ag, and MH2-Ag are the respective silver organic montmorillonite counterparts.

${ }^{\mathrm{a}-\mathrm{f}}$ Different letters in the same column indicate significant differences $(\mathrm{P}<0.05)$

The antimicrobial activity of OMMT samples was also dependent on the assayed microorganism, being less effective against $E$. coli ATCC 25922 (Table 3). The mode of action of quaternary ammonium surfactants involves an association of the charged quaternary nitrogen with the head groups of acidic-phospholipids within the cytoplasmic or inner membrane, this allowing the hydrophobic tail integration into the hydrophobic membrane core of the bacterium and causing the cell to die ${ }^{44}$. E. coli is a gram-negative bacterium; because this enteric bacterium inhabits the mammalian gut, it must have a cell envelope that is particularly effective at excluding some hydrophobic and hydrophilic molecules, as well as detergents such as bile salts ${ }^{45}$. Hence, this outer envelope present in gram-negative bacteria would constitute an additional barrier interfering in $\mathrm{HDMTA}^{+}$ entrance to reach the inner cell membrane, as previously reported for QACs ${ }^{3}$, thus increasing MBC either for the free surfactant and or OMMT (Table 3).

Also, the interaction between the clay and bacteria is important. Because the outermost surface of bacterial cells carries a net negative charge ${ }^{44,45}$, higher positive charges observed by zeta potential measurements upon HDMTA-Br addition to the clay in concentrations higher than the CEC, could lead to an increase in the membrane/OMMT interaction with the corresponding increase in antimicrobial activity.

The addition of $\mathrm{Ag}^{+}$to OMMT samples was studied in order to find out whether antimicrobials targeting different molecules, and having different arrangements within the clay produced different synergistic effects against the assayed microorganisms.

For S. aureus, a marked increase in activity was observed for all samples but $\mathrm{MH} 2-\mathrm{Ag}$ in comparison to their OMMT counterparts (Table 3), indicating synergy of HDMTA ${ }^{+}$and Ag in all cases, even when for MH2$\mathrm{Ag}$ the effect was less pronounced. The later result could be related to antagonist effects obtained when adding silver to OMMT, i.e. higher surfactant loading led to lower interchanged silver proportion (Table 1).

As previously reviewed by Durán et al. ${ }^{5}$ silver ion and silver nanoparticle (AgNPs) activities rely on: (a) the uptake of free silver ions, followed by disruption of ATP production and DNA replication; (b) reactive oxygen species (ROS) generation by AgNPs and silver ions; and (c) direct damage to the cell membrane by AgNPs. In the present work, the presence of silver clusters in MMT-Ag, as suggested by XPS analyses (Fig. 4, Table 1), could be a source of AgNPs with the consequent increase in antimicrobial activity with respect to MMT (Table 3). Furthermore, MBC determinations showed that S. aureus presented lower sensitivity to MMT-Ag than E. coli. This was also described for silver ions, $\mathrm{Ag}_{2} \mathrm{O}$, and $\mathrm{AgNPs}$, and was attributed to the thick peptidoglycan layer in the cell wall of gram-positive microorganisms ${ }^{4,5,46}$.

Besides, as above-stated, $\mathrm{HDMTA}^{+}$was more effective in inhibiting $S$. aureus than $E$. coli due to the outer membrane present in the later bacterium. For MH0.5-Ag sample, even though an increase in activity against $S$. aureus and $E$. coli was obtained with respect to its counterpart, an opposite effect against $E$. coli was observed when comparing MH0.5-Ag to MMT-Ag sample (Table 3). This result could be related to the different 
silver proportions found in both samples (Table 1), coupled with silver and HDMTA ${ }^{+}$mechanisms of action. Hence, $S$. aureus membrane disruption by $\mathrm{HDMTA}^{+}$might allow silver ion entrance to the cell, whereas the surfactant could be retained by the selective $E$. coli membrane, avoiding antimicrobial synergy effects against the later organism (Table 3). Likewise, MH2-Ag, having the highest proportion of HDMTA-Br loaded on the clay and the lower proportion of $\mathrm{Ag}$, mainly as $\mathrm{AgBr}$, presented a similar $\mathrm{MBC}$ to that of $\mathrm{MH} 2$ and higher than that of MMT-Ag against E. coli (Table 3).

These antagonists effects led to the better activity observed for MH1-Ag sample, showing the optimal combination of silver and $\mathrm{HDMTA}^{+}$, which produced a synergy effect against $S$. aureus, while maintaining antimicrobial activity against $E$. coli (Table 3$)$.

Unlike the present work, Savas and Hancer ${ }^{8}$ reported failure to inhibit E. coli when using HDTMAMMT with $100 \%$ CEC loading. The result found by these authors could be attributed to OMMT concentration $(25 \mathrm{mg} / \mathrm{ml})$ below the MIC needed to inhibit the E. coli ATCC 11230 strain. In the present work, MH1 was capable of killing E. coli ATCC 25922 by using $50 \mathrm{mg} / \mathrm{ml}$ of the clay (Table 3). These authors also informed $\mathrm{Ag}^{+-}$HDMTA synergistic effects when assaying $\mathrm{Ag}^{+}$OMMT-LDPE nanocomposite against $E$. coli ATCC 11230 as compared to $\mathrm{OMMT}^{8}$; nevertheless, the comparison was performed avoiding silver MMT effects. As previously discussed in the present work, when looking for possible synergies, is critical to compare all antimicrobials in order to have a complete outlook.

\section{Conclusions}

XPS and zeta potential surface techniques were useful to predict cations' rearrangements that explain the antimicrobial activity behavior of OMMT and OMMT-Ag samples.

The XPS analysis of the $\mathrm{N}_{1 \mathrm{~s}}$ spectra of OMMT-Ag sample showed surfactant adsorption on both the interlayer and the outer clay surface, through a cation-exchange mechanism and Van der Waals interactions, respectively. Furthermore, $\mathrm{C}_{1 \mathrm{~s}}$ spectra analyses established an $\mathrm{HDTMA}^{+}$contact with the clay surface, through the positive head of the ammonium group, avoiding a direct contact between the carbon tail and silica surface.

Surface electric charge modifications on OMMT with respect to MMT sample when surfactant loading increased were attributed to pseudo trilayer and paraffin bilayer arrangements also at the outer surface.

Silver addition generated $\mathrm{Ag}^{0}$ in all OMMT samples in different proportions and species depending on the surfactant loading. For MH0.5-Ag, the presence of surfactant diminished the Ag amount with respect to MMT-Ag sample and clusters were found in both clays. For MH1-Ag and MH2-Ag samples, increasing surfactant loading also decreased the amount of Ag within the clay, MH2-Ag sample showing the presence of $\mathrm{AgBr}$. For MMT-Ag and MH0.5-Ag samples, the presence of $\mathrm{Ag}$ clusters and $\mathrm{Ag}^{0}$ increased the negative zeta potential, whereas the opposite effect was observed for MH1-Ag and MH2-Ag with respect to MMT sample.

The antimicrobial activities of OMMT samples found in this work were intimately related to the surfactant availability within the clay. The decrease in MBC was obtained for samples having surfactant loading over the CEC and HDTMA-Br mainly interacting through weak forces. The addition of silver to OMMT produced synergy effects against $S$. aureus; nevertheless, this effect was not evident for $E$. coli. The result was attributed to the lower sensitivity of the later microorganism to HDTMA-Br coupled with the decrease in silver concentration when the surfactant loading increased within the clay.

This work contributes to the understanding of clay antimicrobial activity involving $\mathrm{HDMTA}^{+}$and silver. This understanding, as well as the awareness of synergy effects, could help in the design of new delivery systems to fight bacteria.

\section{List of Abbreviations}

MMT, montmorillonite

OMMT, organic montmorillonite

HDTMA-Br, hexadecyltrimethylammonium bromide

CEC, cation exchange capacity

MH0.5, MH1, MH2, respectively montmorillonite interchanged with 50, 100 and 200\% of clay cation exchange 


\section{capacity}

MMT-HDMTA-Ag and OMMT-Ag, montmorillonite interchanged with hexadecyltrimethylammonium bromide and silver

QAC, quaternary ammonium compounds

FWHM, full width at half maximum

ZIA, zone of inhibition assay

MBC, Minimum inhibitory bactericidal concentration

CFU, colony-forming units

$\mathrm{BE}$, binding energy

IEP, isoelectric point

AgNPs, silver nanoparticles

\section{References}

1. Wolska K.I., Grzes K. and Anna K., Synergy between novel antimicrobials and conventional antibiotics or bacteriocins. Polish J. Microbiol., 2012, 61(2),95-104.

2. Carmona-Ribeiro A.M. and de Melo Carrasco L.D., Cationic antimicrobial polymers and their assemblies. Int. J. Mol. Sci., 2013,14(5),9906-46.

3. Khalil R.K.S., Selective removal and inactivation of bacteria by nanoparticle composites prepared by surface modification of montmorillonite with quaternary ammonium compounds, World J. Microbiol. Biotechnol. 2013,29(10),1839-50.

4. Jung W.K., Koo H.C., Kim K.W., Shin S., Kim S.H. and Park Y.H., Antibacterial Activity and Mechanism of Action of the Silver Ion in Staphylococcus aureus and Escherichia coli. Appl. Environ. Microbiol., 2008,74(7),2171-8.

5. Durán N., Durán M., de Jesus M.B., Seabra A.B., Fávaro W.J. and Nakazato G., Silver nanoparticles: A new view on mechanistic aspects on antimicrobial activity. Nanomedicine Nanotechnology, Biol. Med., 2016,12(3),789-99.

6. Nayak B.K., Bhat M. A. and Nanda A., Amplification of antibacterial property of drugs in combination with silver nanoparticles synthesized from an airborne fungus, Int.J. ChemTech Res., 2014,6(4), 2368 2373.

7. Kim M.H., Choi G., Elzatahry A., Vinu A., Choy Y. B. and Choy J.H., Review of clay-drug hybrid materials for biomedical applications: Administration routes, Clays Clay Miner., 2016,64(2),115-30.

8. Savas L.A. and Hancer M., Montmorillonite reinforced polymer nanocomposite antibacterial film. Appl Clay Sci., 2015,108,40-4.

9. Sekewael S.J., Wijaya K., Triyono and Budiman A., Nanocomposite of modified montmorillonite K10 with $\mathrm{SiO} 2-\mathrm{Fe} 2 \mathrm{O} 3 \mathrm{as}$ a catalyst of biodiesel synthesis, Int.J. ChemTech Res.,2017, 10(1), 62-70.

10. Malachová K., Praus P., Pavlíčková Z. and Turicová M., Activity of antibacterial compounds immobilised on montmorillonite. Appl. Clay Sci., 2009,43(3-4),364-8.

11. Özdemir G., Yapar S. and Limoncu M.H., Preparation of cetylpyridinium montmorillonite for antibacterial applications, Appl. Clay Sci., 2013,72,201-5.

12. Magaña S.M., Quintana P., Aguilar D.H., Toledo J.A., Ángeles-Chávez C., Cortés M.A., Leon L., Freile-Pelegrin Y., Lopez T. and Torres Sanchez R.M., Antibacterial activity of montmorillonites modified with silver, J. Mol. Catal. A Chem., 2008,281(1-2),192-9.

13. Özdemir G., Limoncu M.H. and Yapar S., The antibacterial effect of heavy metal and cetylpridiniumexchanged montmorillonites, Appl. Clay Sci., 2010,48(3),319-23.

14. Negi H., Agarwal T., Zaidi M.G.H., Kapri A. and Goel R., Antimicrobial organophilic montmorillonite nanoparticles: Screening and detection assay, Biotechnol. J. 2011,6(1),107-12.

15. Lamarra J., Fernández M., Pascual Cosp J., de la Fournière S., Garbossa G. and Torres Sánchez R.M., Water decontamination by silver and copper montmorillonite, Int. J. Environ, Heal., 2014,7(1),15-30.

16. Nigmatullin R., Gao F. and Konovalova V., Polymer-layered silicate nanocomposites in the design of antimicrobial materials, J. Mater. Sci., 2008,43(17),5728-33.

17. He H., Ma Y., Zhu J., Yuan P. and Qing Y., Organoclays prepared from montmorillonites with different cation exchange capacity and surfactant configuration, Appl. Clay Sci., 2010,48(1-2),67-72.

18. Magnoli A.P., Tallone L., Rosa C.A.R., Dalcero A.M., Chiacchiera S.M. and Torres Sanchez R.M., Commercial bentonites as detoxifier of broiler feed contaminated with aflatoxin, Appl. Clay Sci., 2008,40(1-4),63-71. 
19. Gamba M., Flores F.M., Madejová J. and Torres Sánchez R.M., Comparison of Imazalil Removal onto Montmorillonite and Nanomontmorillonite and Adsorption Surface Sites Involved: An Approach for Agricultural Wastewater Treatment, Ind. Eng. Chem. Re., 2015,54(5),1529-38.

20. Moulder J.F. and Chastain J., Handbook of X-ray photoelectron spectroscopy: a reference book of standard spectra for identification and interpretation of XPS data. Physical Electronics Division, PerkinElmer Corp, 1992, 259.

21. Schampera B., Tunega D., Šolc R., Woche S.K., Mikutta R., Wirth R., Dultz S. and Guggenberger G., External surface structure of organoclays analyzed by transmission electron microscopy and X-ray photoelectron spectroscopy in combination with molecular dynamics simulations, J. Colloid Interface Sci., 2016,478,188-200.

22. Sondi I. and Salopek-Sondi B., Silver nanoparticles as antimicrobial agent: A case study on E. coli as a model for Gram-negative bacteria, J. Colloid Interface Sci, 2004,275(1),177-82.

23. Torres Sánchez R.M., Genet M.J., Gaigneaux E.M., dos Santos Afonso M. and Yunes S., Benzimidazole adsorption on the external and interlayer surfaces of raw and treated montmorillonite, Appl. Clay Sci., 2011,53(3),366-73.

24. Naranjo P.M., Sham E.L., Castellón E.R., Torres Sánchez R.M. and Farfán Torres E.M., Identification and Quantification of the Interaction Mechanisms Between the Cationic Surfactant HDTMA-Br and Montmorillonite, Clays Clay Miner., 2013,61(2),98-106.

25. Seki Y. and Yurdakoç K., Paraquat adsorption onto clays and organoclays from aqueous solution, J Colloid Interface Sci., 2005,287(1),1-5.

26. He H., Zhou Q., Frost R.L., Wood B.J., Duong L.V. and Kloprogge J.T., A X-ray photoelectron spectroscopy study of HDTMAB distribution within organoclays, Spectrochim. Acta - Part A Mol. Biomol. Spectrosc., 2007,66(4-5),1180-8.

27. Liu G., Wu S., van de Ven M., Molenaar A. and Besamusca J., Characterization of Organic Surfactant on Montmorillonite Nanoclay to Be Used in Bitumen, J. Mater. Civ. Eng., 2010,22(8),794-9.

28. Wang X., Yuan S., Chen S., Chen G., Zhang J. and Zhang L., Synthesis of Ag3PO4-AgBr with a novel heterostructure, and its photocatalytic properties, Res. Chem. Intermed., 2014,41(8),5137-47.

29. Liu X-H., Luo X-H., Lu S-X., Zhang J-C. and Cao W-L., A novel cetyltrimethyl ammonium silver bromide complex and silver bromide nanoparticles obtained by the surfactant counterion, J. Colloid Interface Sci., 2007,307(1),94-100.

30. Oyanedel-Craver V.A. and Smith J.A., Effect of quaternary ammonium cation loading and $\mathrm{pH}$ on heavy metal sorption to Ca bentonite and two organobentonites, J. Hazard Mater., 2006,137(2),1102-14.

31. Song J., Shi Y., Ren M.and Hu G., Synthesis, characterization and excellent photocatalytic activity of $\mathrm{Ag} / \mathrm{AgBr} / \mathrm{MoO} 3$ composite photocatalyst., Appl. Phys. A. 2014,116(4),2139-47.

32. Lavorgna M., Attianese I., Buonocore G.G., Conte A., Del Nobile M.A., Tescione F. and Amendola E., MMT-supported Ag nanoparticles for chitosan nanocomposites: Structural properties and antibacterial activity, Carbohydr. Polym., 2014,102(1),385-92.

33. Calderon V.S., Galindo R.E., Benito N., Palacio C., Cavaleiro A. and Carvalho S., Ag+release inhibition from $\mathrm{ZrCN}-\mathrm{Ag}$ coatings by surface agglomeration mechanism: Structural characterization, J. Phys. D. Appl. Phys. 2013,46(32).

34. Bootharaju M.S., Pradeep T. and An X., Uptake of toxic metal ions from water by naked and monolayer protected silver nanoparticles: ray photoelectron spectroscopic investigation, J. Phys. Chem. C., 2010,114 SRC-(1 mM),8328-36.

35. Mikhlin Y.L., Vishnyakova E.A., Romanchenko A.S., Saikova S.V., Likhatski M.N., Larichev Y.V., Tuzikov F.V., Zaikovskii V.I. and Zharkov S.M., Oxidation of Ag nanoparticles in aqueous media: Effect of particle size and capping, Appl. Surf. Sci., 2014,297,75-83.

36. Bianchi A.E., Fernández M., Pantanetti M., Viña R., Torriani I., Torres Sánchez R.M. and Punte G., ODTMA+ and HDTMA+ organo-montmorillonites characterization: New insight by WAXS, SAXS and surface charge, Appl. Clay Sci., 2013,83-84,280-5.

37. Zadaka D., Radian A. and Mishael Y.G., Applying zeta potential measurements to characterize the adsorption on montmorillonite of organic cations as monomers, micelles, or polymers, J. Colloid Interface Sci., 2010,352(1),171-7.

38. Praus P., Turicová M., Študentová S. and Ritz M., Study of cetyltrimethylammonium and cetylpyridinium adsorption on montmorillonite, J. Colloid Interface Sci. 2006,304(1),29-36.

39. Shen W., Feng L., Feng H. and Lei A., Divalent silver oxide-diatomite hybrids: Synthesis, characterization and antibacterial activity, Ceram. Int., 2013,39(5),5013-24.

40. Sadowski T., Maliszewska Z., Grochowalska I.H., Polowczyk B. and Koźlecki I., Synthesis of silver 
nanoparticles using microorganisms. Mater. Sci. Pol., 2008, 26, 419-424.

41. Selmani A., Lützenkirchen J., Kallay N. and Preočanin T., Surface and zeta-potentials of silver halide single crystals: PH-dependence in comparison to particle systems, J. Phys. Condens. Matter., 2014,26(24).

42. Green J-B.D., Fulghum T. and Nordhaus M.A., A review of immobilized antimicrobial agents and methods for testing, Biointerphases, 2011,6(4),MR13-MR28.

43. Parolo M., Fernandez L., Zajonkovsky I., Sanchez M. and Baschini M., Antibacterial activity of materials synthesized from clay minerals, Sci. against Microb. Pathog. Commun. Curr. Res. Technol. Adv., 2011,144-51.

44. Gilbert P. and Moore L.E., Cationic antiseptics: Diversity of action under a common epithet, J. Appl. Microbiol. 2005,99(4),703-15.

45. Silhavy T.J., Kahne D. and Walker S., The bacterial cell envelope, Cold Spring Harb. Perspect. Biol., 2010,2(5),1-16.

46. Negi H., Rathinavelu Saravanan P., Agarwal T., Ghulam Haider Zaidi M. and Goel R., In vitro assessment of $\mathrm{Ag} 2 \mathrm{O}$ nanoparticles toxicity against Gram-positive and Gram-negative bacteria, J. Gen. Appl. Microbiol., 2013,59(1),83-8. 